\title{
The Correlation between Online Comments before Broadcasting and Television Content Viewers' Behavior Pattern: The Anchoring Effect Perspective
}

\author{
Alice Kyungran $\mathrm{Ma}^{1}$ and Jongchang $\mathrm{Ahn}^{2}$ \\ ${ }^{1}$ Department of Media \& Technology Management, University of Cologne \\ Cologne, 50969 - Germany \\ [e-mail: kma1@smail.uni-koeln.de] \\ ${ }^{2}$ Department of Information Systems, Hanyang University \\ Seoul, 04763 - Republic of Korea \\ [e-mail: ajchang@hanyang.ac.kr] \\ *Corresponding author: Jongchang Ahn
}

Received January 12, 2018; revised August 23, 2018; revised December 8, 2018; accepted December 13, 2018; published June 30, 2019

\begin{abstract}
This study investigated the television (TV) content viewers' behavior influenced by online communication at the choice of new TV series on a terrestrial streaming platform. For exploring the impact of the anchoring effect on the TV content consumption, this study analyzed the correlation between the first episode's TV ratings and the data of online comments or reactions. These data were potential audiences' communication, which were generated on the online article three weeks before the first broadcasting began. To avoid the crucial influence by external factors, such as season and social issue, the test was done with eight (8) TV series which have same genre (drama), similar core audience targeting (20-49's women), similar broadcasting period (Jun-Oct 2016), same scheduling (10.00 to $11.00 \mathrm{pm}$, weekdays) and aired on terrestrial TV platforms. This research found that not only the amount of comments and reactions, but also the attitude about the comments created before broadcasting, positively influence the audiences' decision-making behavior for new TV content choices. This investigation contributes to the literature on media economics and management by exploring the media content users' consuming behavior with behavioral economics perspectives (anchoring effect) and making a first step for finding a new effect on the media content consumption.
\end{abstract}

Keywords: Comments ${ }^{1)}$ and reactions ${ }^{2)}$, television (TV) viewers, willingness to watch, TV ratings ${ }^{3)}$, anchoring effect

A preliminary version of this paper appeared in 2017 Annual Conference of the European Media Management Association (emma), May 10-12, Ghent, Belgium. This version includes a concrete analysis and significant result. "This research was supported by Basic Science Research Program through the National Research Foundation of Korea(NRF) funded by the Ministry of Education(2017R1D1A1B03031824).“ 
1) Comment is a user-generated web content to an online article.

2) Reaction is a reader's action to express his/her emotion to a comment by clicking a like button (vote up/favor/recommend) or dislike button (vote down/non-flavor).

3) TV ratings represent the viewing rate for TV content, and the data were collected from Nielsen.

\section{Introduction}

Under uncertainty, for making a decision on the judgment or predicting something, people rely on a limited number of heuristic principles. This tendency reduces the complex tasks of assessing probabilities and predicting values to simpler judgmental operations [1]. People's decisions often express affective evaluations, which do not conform to the logic of economic preferences [2]. People tend to focus on the first available piece of information (the "anchor") given to them when making decisions. In many situations, people make estimates by starting from an initial value that is adjusted to yield the final answer. This phenomenon is called anchoring, and it particularly affects decisions regarding numerical values [1].

The literature indicates that, in decision making, the higher the ambiguity, the lower the familiarity, relevance or personal involvement with the problem; a more trustworthy source or plausible bid/estimate, the stronger the anchoring effect [4]. Media products such as TV content are relevant to this type, which is very difficult to predict the degree of entertainment and the quality of the content itself. Media product is concerned with both information and creativity. Note that we narrowly consider the media product as TV content, especially TV drama series.

Media product, including TV content, is an experiential product. The dominant benefit of experiential products is hedonic consumption, that is the feelings, emotions, and sensations experienced during product usage [5]. Because of these characteristics, it is very hard to predict the quality and the value of the new content. If some new TV series are broadcasted at the same scheduling time, which content will be selected? What will influence the viewers' choice? This decision is often not easy for content consumers, producers, TV station managers, and researchers. How is the decision of content choice to be made among competitive media contents?

To predict the value of a new TV series content, in other words, to choose what to watch in prime time, viewers try to obtain a variety of information. The audience and web users will likely expect to obtain gratification from online news and another programming-related content from a station website [7]. Individuals use various media devices to search for additional information [8], for example visiting a website mentioned in the program, or checking fact information about a show [9]. In addition to reading online entertainment news articles, viewers check the number and context of comments/replies regarding the actors, genre, script, and producers. The audience also check the reaction data (good or bad) to the comments and replies.

At this moment, do these numbers of comments and reactions data play the role as the initially presented value of the anchoring effect theory [4]? Do they affect the viewers' decision-making process to consume the TV content? Do other factors which affect the TV content choice exist? This research aims to make the first step to apply the anchoring effect to TV content consumption empirically, building on the following research question: What affects the audience's willingness to watch TV content? 
The anchoring effect is one of the most robust cognitive heuristics. Previous literature has examined many different domains and tasks in all decision making processes. The examples of these domains are general knowledge, probability estimate, legal judgment, valuation/purchasing decision, and forecasting. In addition, these are studied with material goods having characteristics of excludability, expendability, rivalry and their market [10].

Being different from material goods, TV content as one of the most important media products is goods with the attributes of non-excludability, non-expendability, interdependence of utility, and powerful social effect. Media economy is the 'attention economy' [11]. Anyone who is unwilling to pay for TV content can access the broadcasting service with bundling commercial advertisement. This is not the case of Adam Smith's invisible hand which applies to the material goods.

Broadcasting business is the selling of audiences to advertisers - the larger the audience, the higher the commercial rates. The broadcaster has to capture their audience as long as possible and as many as possible (higher TV ratings) for advertisement sales revenue. In the case of TV series content, the ratings and evaluation of the first episode are crucially important. From a research perspective of the anchoring effect theory, this study investigates if the behavior of acquiring and sharing information about the new content before broadcasting can influence the viewers' willingness to watch. This paper analyzed the correlation between the number of comments/reactions and TV ratings. The data of comments and reactions on the online news are acquired from web crawler (bot) software; the TV ratings are gathered from the Nielsen Company (www.nielsen.com).

The remainder of this paper is organized as follows: Section 2 reviews the relevant literature. Section 3 outlines the research design, and Section 4 describes the method used for data collection and empirical analysis. Analytical results are reported in Section 5. Section 6 discusses and concludes the proposed research, including further research and limitations.

\section{Literature Review}

As mentioned previously, this study is to explore the media content users' consuming behavior with the behavioral economics perspective (anchoring effect) by analyzing the online big data based on viewers' comments and reactions. Here we narrowly investigate the media content with the TV drama series on terrestrial streaming service, so media content users' behavior is to watch TV. Viewers' watching behavior leads to higher viewing rates and increasing advertising revenue. This research can be the first convergence study of media management and media consumers' heuristic behavior with online comments number and data, so we review the three fields of literature.

\subsection{Media Management and Economics}

The scholars who studied theoretical tradition sphere have tried to explain choices, decisions, and other economic factors which are affecting producers and consumers of communications goods or services. They have designed to support forecasts for the prospects and effects of the development of media $[9,10,11]$. The applied tradition emerged from business, economics, and management has often explored the structure of communication industries and their markets. It includes an emphasis on understanding trends and changes responding to the transition in the economy and consumer behavior [15].

As time progressed, the issue of the appearance of new media has become more significant. A great deal of change in communications has resulted in changing technologies and questions raised about those changes [15]. Technological change is an inevitable and underlying force of 
progress in media industries. Volume and velocity of those changes pose a great challenge to all media sectors [16]. Technological development and innovation lead the media to one of a handful of industries.

The radio industry survived with a unique type of media in spite of the emergence of TV. Similarly, TV watching patterns will exist as an important viewing behavior in a very competitive era with digitalized products, multi-platforms, multi-devices and multi-channel. Instead, today TV audiences are experiencing greater control over how they consume TV in the platforms that best suit their needs. Increasing numbers of TV viewers with internet access are tele-webbing or surfing the web while watching TV [17]. Social TV viewing is emerging as a noteworthy phenomenon - the act of social media while watching TV [18]. Watching TV content and communicating with other audiences often simultaneously happen in online space.

\subsection{Social Engagement among TV Content Users}

Social engagement refers to the degree of interactions or connections that a viewer develops with TV content through various social media [6]. It has been suggested that engagement is primarily driven by program content in the TV consumption context, and the deepest engagement experience happens at the content level [19].

The combination of TV and social media is developing into a new killer application in the digitalized media era. This combination allows simultaneous viewing desire (to see live broadcasting) and communication desire (to express various opinions on the desired TV shows) (www.tvnewscheck.com), meaning that viewers' communication desire for TV shows is strong. As a tool for measuring viewers' behavioral patterns in social media, social impression (calculated by measuring conversation volume, page views, number of visitors, and attributes of the people who write comments, reply, or debate each other in social media) will play an important role in determining the flow of money [20]. The information generated as a result of user interactions on social networking sites influences the decision-making process of consumers [21].

The marriage between traditional TV and the emerging social media can be attributed to the growing adoption of social media tools by consumers and their increasing cross-platform and multitasking pattern [8]. Viewer engagement is "a more passion-driven and more socially driven mode of watching TV" across as many platforms as possible [22].

While previous research focused on the phenomenon of social engagement during the TV shows' broadcasting period, this study aims to explore the implication with the data created during three weeks in advance from the first broadcast. The forms of those data are comments on online news articles concerned with the new content, and reaction (good/bad or favor/ non-favor) to the comments.

\subsection{Anchoring Effect}

Heuristics are characterized as an 'intuitive, rapid, and automatic system' [23], which 'reduce the complex tasks of assessing probabilities and predicting values to simpler judgmental operations.' Although the use of rules of thumb reduces cognitive and time constraints, sometimes they lead to severe and systematic errors such as biases and fallacies in decision making [4]. One of the representative heuristics is anchoring heuristic, which is a ubiquitous phenomenon in human judgment.

The anchoring-and-adjustment heuristics [4], first introduced by Tversky and Kahneman in their pioneering work on judgment under uncertainty, could be the main anchoring effect referred to in the current study. The heuristic maintains that insufficient adjustment causes anchoring bias because final judgments are assimilated toward the starting point of a judge's 
deliberations. The anchoring effect is the disproportionate influence on decision-makers to make judgments that are biased toward an initially presented value [4]. Following their study, many studies have illustrated the prevalence of anchoring effect in human decision-making processes. For TV content, four specific fields can be applied; valuations/purchasing decisions [24], forecasting [25,26] among domains, attitude change among perspectives [27,28,29], and knowledge/experience/expertise among human factors [25,30,31].

As previously written, in decision making, the higher the ambiguity, the lower the familiarity, relevance or personal involvement with the problem; a more trustworthy source or plausible bid/estimate, the stronger the anchoring effects [5]. Estimates are biased toward the anchor values. Strack and Mussweiler explained, "Anchor values serve as the reference point for people to adjust the boundary of the range of plausible values for the question, presuming that the given anchor is more extreme than the boundary value for the range of plausible answers [32]."

Therefore, we can assume that if the viewer sees the extremely high number of comments about the new TV content, the influence on the judgment of content choice and the content evaluation could also be high. This research also assumes that the number of comments and reactions generated before broadcasting is considered as an initially presented value for forecasting and decision making to select TV content, whereas the viewer ratings reflect the TV content consumers' behavior pattern.

\section{Research Design}

There are factors affecting TV audiences' viewing behavior positively or negatively; different platform (terrestrial, cable network, IPTV, and satellite), various devices (television, computer, tablet, smartphone, etc.), viewing method (live streaming or VOD), and many competitive channels. Based on creative hedonic content perspective, main actors, scripters, story theme, public relation, and potential audiences' communication are also important factors of viewing. Viewers communicate with other viewers. Consequently, those comments and discussion might influence viewers to watch a TV program [33]. Online communication data can be a source of up-to-date information to make a final decision making, e.g., to do, do not, or stop watching TV drama [34]. The study about the correlation between SNS data and TV viewing ratings was performed in the previous research [35]. This study focused on representative three terrestrial channels' eight TV drama series aired on all platforms to minimize technical interference factors.

\subsection{Conceptual Framework}

Fig. 1 presents a formal model to explore the process of audiences' decision making for the choice of new TV content correlated with the information of online data value. In addition, Fig. 2 presents the model to demonstrate how anchoring effect influences on audiences' willingness to watch TV content (consumers' behavior) under the anchoring-and-adjustment mechanism. The number of comments and reactions on the online news is considered as the initially presented value of the anchoring effect and also considered the TV ratings as the judgment index of content choice behavior. This study tested a research model through exploratory research by analyzing TV ratings data gathered from the Nielsen (www.nielsen.com) combined with buzz data like comments and reactions on online news articles. These buzz data were collected from a Korean oligopolistic portal site using the crawling software. 

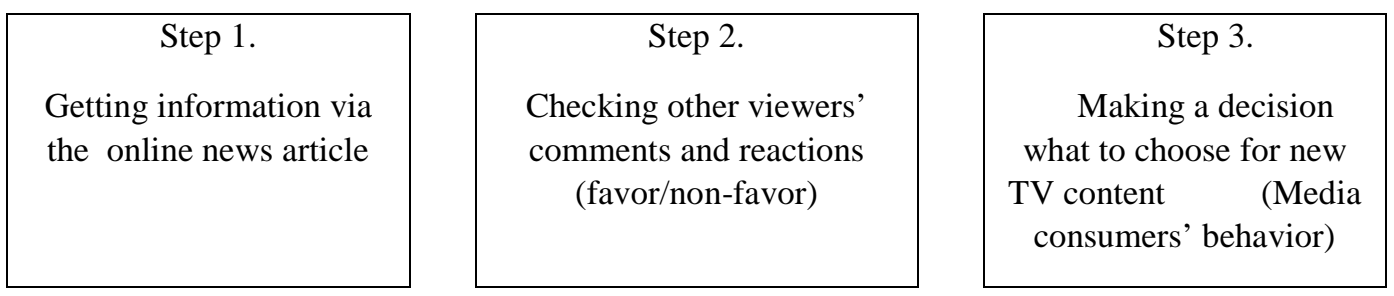

Fig. 1. The process of audiences' decision making for new TV content by online data

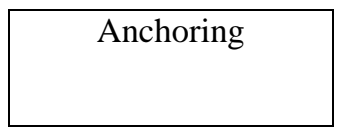

\begin{tabular}{|l|}
\hline Reading consumers' \\
online \\
communication data \\
to online articles \\
about a new content \\
-Num of comments \\
-Num of Reactions \\
(favor/non-favor) \\
\end{tabular}

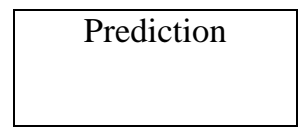

\begin{tabular}{|l|}
\hline $\begin{array}{l}\text { Predicting the } \\
\text { value of a new } \\
\text { content }\end{array}$ \\
Affected by other \\
consumers \\
comments \\
context and the \\
number
\end{tabular}

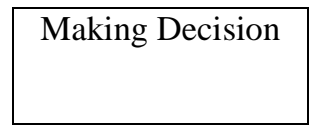

\begin{tabular}{|l|}
\hline Making a \\
judgment for a \\
new TV content \\
for the first \\
watching choice \\
Affects the WTW \\
(Willingness to \\
Watch) \\
\end{tabular}

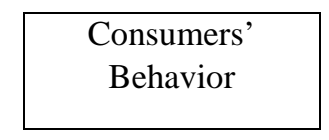

Watching the TV
content that was
decided by the
process of media
content viewing
TV ratings reflect
the media
consumers'
watching behavior

Fig. 2. The process of viewing behavior with the perspective of the anchoring effect

In this paper, the concrete definitions of key terms need to be described:

- TV ratings represent the viewing rate for TV content. All ratings data were gathered from Nielsen and measured in ATS (=EA/Reach) where ATS (Average TV Shares) means an average of the audience expressed in minutes and EA means estimated audience and Reach means scope. TV ratings reflect the percentage of the total population of TV tuned to a particular program (Nielsen).

- The comment is the text written in some article to express reader's opinion, including positive and negative comments.

- The reaction (favor/non-favor or like/dislike) is directly combined with the comment of online news articles. The online users leave their feeling by clicking the favor or non-favor button after reading the news and comments.

\subsection{Research Hypotheses}

From the basic research question (What affects the audience's willingness to watch TV content?), exploratory hypotheses can be offered that resonate with the proposed theoretical approach. As mentioned above, this paper investigates how the anchoring effect influences audiences' willingness to watch TV content (consumers' behavior) with the comments and reactions data as an initially presented value. This purpose leads to the following hypotheses. 
H1 : $\quad$ The number of comments and reactions (initially presented value $=$ anchor) positively affects the audiences' decision making of the willingness to watch (WTW).

H1-1: The total number of comments (positive and negative) positively affects the audiences' decision making of the WTW.

H1-2: The total number of comments with regard to the attitude of reactions (favor or non-favor) positively affects the audiences' decision making of the WTW.

H1-3: The total number of comments with regard to the amount of reactions (favor and non-favor) positively affects the audiences' decision making of the WTW.

\section{Method}

\subsection{Data Collecting}

The main online data source of comments and reactions is from a website, which is an internet content service operator with a searching portal in oligopolistic position in South Korea. With eight titles of TV series, 16,929 comments, and 957,908 reactions by the process of crawling using PHP (Hypertext Preprocessor) and filtering with the regular formation of the Linux su command were collected. The text mining of comments was manually done for the accurate analysis of the complex and ambiguous expression in comments. As mentioned previously, TV ratings represent the viewing rate for TV content. All ratings data were gathered from Nielsen (www.nielsen.com). To avoid the crucial influence by external interference factors, such as season and social issue, the test was done with eight titles of TV series which have same genre (drama), similar core audience targeting (20-49's women), similar broadcasting period (June - October of 2016), same scheduling (22:00-23:00 on weekdays) and aired on terrestrial TV platform like Table 1.

Table 1. The titles of tested TV series

\begin{tabular}{|c|c|c|c|c|}
\hline Title & $\begin{array}{c}\text { The first } \\
\text { broadcasting day }\end{array}$ & $\begin{array}{c}\text { Three week } \\
\text { period for online } \\
\text { data }\end{array}$ & $\begin{array}{l}\text { Genre } \\
\text { (drama) }\end{array}$ & $\begin{array}{l}\text { Platform/Channel } \\
\text { (in Korea) }\end{array}$ \\
\hline Beautiful Mind & 20.06 .2016 & $31.05-20.06$ & Medical & Terrestrial (KBS) \\
\hline $\begin{array}{l}\text { Carrying } \\
\text { Woman }\end{array}$ & 26.09.2016 & $05.09-26.09$ & Detective & $\begin{array}{c}\text { Terrestrial } \\
\text { (MBC) }\end{array}$ \\
\hline $\begin{array}{l}\text { Couple of } \\
\text { Moon }\end{array}$ & 29.08.2016 & $08.08-29.08$ & Historic & Terrestrial (SBS) \\
\hline Doctors & 20.06.2016 & $31.05-20.06$ & $\begin{array}{l}\text { Medical } \\
\text { romance }\end{array}$ & Terrestrial (SBS) \\
\hline God of Jealousy & 24.08.2016 & $03.08-24.08$ & $\begin{array}{l}\text { Romantic } \\
\text { comedy }\end{array}$ & Terrestrial (SBS) \\
\hline $\begin{array}{l}\text { King of } \\
\text { Shopping }\end{array}$ & 21.09.2016 & $31.08-21.09$ & $\begin{array}{l}\text { Romantic } \\
\text { comedy }\end{array}$ & $\begin{array}{c}\text { Terrestrial } \\
\text { (MBC) }\end{array}$ \\
\hline W & 20.07.2016 & $30.06-20.07$ & Fantasy & $\begin{array}{l}\text { Terrestrial } \\
\text { (MBC) }\end{array}$ \\
\hline Way to Airport & 21.09.2016 & $31.08-21.09$ & Romance & Terrestrial (KBS) \\
\hline
\end{tabular}

\subsection{Operationalization and Measurement of Variables}

The model for assessing the hypotheses comprises three independent variables of the total number of comments, and two adjusted number of comments with reactions, and one dependent variable, TV ratings. Table 2 presents data of dependent and independent variables. 
Independent variables (Initially presented value)

$\mathrm{X}_{1}$ : The total number of comments (positive and negative)

$\mathrm{X}_{2}$ : The total number of comments with regard to the attitude of reactions (favor or non-favor)

$\mathrm{X}_{3}$ : The total number of comments with regard to the amount of reactions $i$ : The order of comment on a news article (e.g., the $i$ th comment on an article) $\beta:+1$ (if the comment is favor)

-1 (if the comment is non-favor)

$\alpha i$ : The number of favor reactions (good) on the $i$ th comment $b_{i}$ : The number of non-favor reactions (bad) on the ith comment $x_{i}$ : Variable of the number of comments on the ith news article $\mathrm{Y}_{j}$
(1) $\mathrm{X}_{1}=\sum_{i=1}^{n}|\beta| \mathrm{x}_{i}$
(2) $\mathrm{X}_{2}=\sum_{i=1}^{n} \beta \mathrm{x}_{i}\left(a_{i}-b_{i}\right)$
(3) $\mathrm{X}_{3}=\frac{\sum_{i=1}^{n} \beta \mathrm{x}_{i}\left(a_{i}+b_{i}\right)}{\sum_{i=1}^{n}\left(a_{i}+b_{i}\right)}$

- Dependent Variable

$Y_{j}=\mathrm{TV}$ ratings of $1^{\text {st }}$ episode of TV series drama $j(j=1,2,3 \ldots 8)$

Table 2. Data of one dependent variable and three independent variables

\begin{tabular}{|c|c|c|c|c|c|}
\hline & $(\mathrm{Y})$ & $\left(X_{1}\right)$ & $\left(X_{2}\right)$ & $\left(X_{3}\right)$ & \\
\hline Title & $\begin{array}{c}\text { The Ratings } \\
\text { of the first } \\
\text { episode }\end{array}$ & $\begin{array}{l}\text { The total } \\
\text { number of } \\
\text { comments }\end{array}$ & $\begin{array}{l}\text { The total } \\
\text { number of } \\
\text { comments } \\
\text { with the } \\
\text { attitude \& } \\
\text { amount of } \\
\text { reactions }\end{array}$ & $\begin{array}{l}\text { The total } \\
\text { number of } \\
\text { comments } \\
\text { with the } \\
\text { amount of } \\
\text { reactions }\end{array}$ & $\begin{array}{l}\text { Grouping } \\
\text { according to } \\
\text { TV viewer } \\
\text { ratings }\end{array}$ \\
\hline Doctors & 5.617 & 2,792 & 122,622 & 0.714 & \multirow{3}{*}{$\begin{array}{c}\text { Higher } \\
\text { Ratings } \\
\text { Group } \\
\text { ( H ) }\end{array}$} \\
\hline $\begin{array}{c}\text { Couple of } \\
\text { Moon }\end{array}$ & 3.980 & 4,278 & 132,749 & 0.531 & \\
\hline W & 4.327 & 2,096 & 88,379 & 0.665 & \\
\hline $\begin{array}{c}\text { God of } \\
\text { Jealousy }\end{array}$ & 2.937 & 1,750 & 32,263 & 0.318 & \multirow{5}{*}{$\begin{array}{l}\text { Lower } \\
\text { Ratings } \\
\text { Group } \\
\text { ( L ) }\end{array}$} \\
\hline $\begin{array}{l}\text { Beautiful } \\
\text { Mind }\end{array}$ & 1.991 & 1,353 & 15,331 & 0.295 & \\
\hline $\begin{array}{l}\text { Way to } \\
\text { Airport }\end{array}$ & 3.077 & 1,640 & 11,431 & 0.111 & \\
\hline $\begin{array}{l}\text { Carrying } \\
\text { Woman }\end{array}$ & 2.428 & 1,250 & 26,941 & 0.612 & \\
\hline $\begin{array}{l}\text { King of } \\
\text { Shopping }\end{array}$ & 2.546 & 1,770 & 83,360 & 0.814 & \\
\hline
\end{tabular}

Note that the TV ratings (provided by Nielsen) are gathered under the conditions; marketKorean national, variable- AMR (Average Minute Ratings, \%), platform- all (terrestrial, cable, IPTV), target-individual with the people-meter data collecting method. 


\section{Results}

\subsection{Regression Analysis}

The reliability of measured items was tested as a consistency index. In the case of having many variations among variables, Cronbach's Alpha value based on standardized items was recommended and used [36]. The value is 0.813 in Table 3, so the measured items are considered reliable. Scales with reliabilities of 0.7 or greater are recommended in social science research [36]. The stepwise regression is a method for dividing effective and ineffective variables based on the significance of each partial regression coefficient. Table 4 and Table 5 present that only X2 variable significantly explained TV ratings as a dependent variable (the adjusted $\mathrm{R}^{2}$ value is 0.511 ). Thus, H1-2 (The number of comments with the attitude of reaction positively affects the audiences' willingness to watch) was accepted. The F-value (8.324) was presented significantly under p-value (0.028) at a 0.05 level and presented a significant regression equation. The standardized beta coefficient value was 0.762 and $\mathrm{t}$-value 2.885 .

To check the concern of the potential existence of multi-collinearity problem, we examined it formally by using variance inflation factor (VIF), which indicates the degree to which each predictor variable is explained by predicted variables, is a common measure of multi-collinearity in regression analysis. In this study, the multi-collinearity problem is not in question because VIF presented 1 in the recommended criteria below 10 [37,38], and Tolerance presented 1 in the recommended criteria over 0.1. The Durbin-Watson value is 1.978 in the recommended criteria near 2.0, which presented no correlation among residuals.

Table 3. Reliability Statistics

\begin{tabular}{|c|c|c|}
\hline Cronbach's Alpha & $\begin{array}{l}\text { Cronbach's Alpha Based } \\
\text { on Standardized Items }\end{array}$ & Number of Items \\
\hline .050 & .813 & 3 \\
\hline
\end{tabular}

Table 4. Coefficients

\begin{tabular}{|c|c|c|c|c|c|c|c|c|c|c|}
\hline \multirow{2}{*}{\multicolumn{2}{|c|}{ Model }} & \multicolumn{2}{|c|}{$\begin{array}{l}\text { Unstandardized } \\
\text { Coefficients }\end{array}$} & \multirow{2}{*}{\begin{tabular}{|c|}
$\begin{array}{c}\text { Standardized } \\
\text { Coefficients }\end{array}$ \\
Beta \\
\end{tabular}} & \multirow{2}{*}{$\mathrm{t}$} & \multirow{2}{*}{ Sig. } & \multicolumn{2}{|c|}{$\begin{array}{l}\text { 95\% Confidence } \\
\text { Interval for B }\end{array}$} & \multicolumn{2}{|c|}{$\begin{array}{l}\text { Collinearity } \\
\text { Statistics }\end{array}$} \\
\hline & & B & Std. Error & & & & $\begin{array}{l}\text { Lower } \\
\text { Bound }\end{array}$ & $\begin{array}{l}\text { Upper } \\
\text { Bound }\end{array}$ & Tolerance & VIF \\
\hline \multirow[t]{2}{*}{1} & (Constant) & 2.160 & .512 & & 4.221 & .006 & .908 & 3.412 & & \\
\hline & $\mathrm{X} 2$ & 1.8765 & .000 & .762 & 2.885 & .028 & .000 & .000 & 1.000 & 1.000 \\
\hline
\end{tabular}

a. Dependent Variable: $\mathrm{Y}$

Table 5. Model Summary ${ }^{\mathrm{b}}$

\begin{tabular}{|c|c|c|c|c|c|c|c|c|c|c|}
\hline \multirow[b]{2}{*}{ Model } & \multirow[b]{2}{*}{$\mathrm{R}$} & \multirow{2}{*}{$\begin{array}{c}\mathrm{R} \\
\text { Square }\end{array}$} & \multirow{2}{*}{$\begin{array}{c}\text { Adjusted } \\
\mathrm{R} \\
\text { Square }\end{array}$} & \multirow{2}{*}{$\begin{array}{l}\text { Std. Error } \\
\text { of the } \\
\text { Estimate }\end{array}$} & \multicolumn{5}{|c|}{ Change Statistics } & \multirow[b]{2}{*}{$\begin{array}{l}\text { Durbin- } \\
\text { Watson }\end{array}$} \\
\hline & & & & & $\begin{array}{l}\text { R Square } \\
\text { Change }\end{array}$ & \begin{tabular}{|c|}
$\mathrm{F}$ \\
Change
\end{tabular} & df1 & df2 & & \\
\hline 1 & $.762^{\mathrm{a}}$ & .581 & .511 & 838795 & .581 & 8.324 & 1 & 6 & .028 & 1.978 \\
\hline
\end{tabular}

a. Predictors: (Constant), X2

b. Dependent Variable: Y 


\subsection{T-test Analysis}

An independent two-sample t-test was used to investigate whether the mean of comments with the reaction differs by TV ratings which can be classified into Higher Ratings Group ( $\mathrm{H}-3$ titles) and Lower Ratings Group ( $\mathrm{L}-5$ titles) like Table 2. Levene's test for equality of variances was used. As shown in Table 6, the result of t-test analysis is that only independent variable $\mathrm{X}_{2}$ has statistical significance at a 0.01 level. The significant probability is 0.849 ( $>0.01$ ) for the independent variable $\left(\mathrm{X}_{2}\right)$, it is impossible to reject the $\mathrm{H} 0$ (null hypothesis). Therefore equal variances were assumed. The t-value is 4.068 and $p$-value is $0.007(p<0.01)$. Thus, the two groups have a significant difference in $\mathrm{X}_{2}$ variable.

Table 6. Independent Samples Test

\begin{tabular}{|c|c|c|c|c|c|c|c|c|c|c|}
\hline & \multicolumn{2}{|c|}{$\begin{array}{l}\text { Levene's } \\
\text { Test for } \\
\text { Equality of } \\
\text { Variances }\end{array}$} & \multicolumn{7}{|c|}{ t-test for Equality of Means } \\
\hline & & \multirow[t]{2}{*}{$\mathrm{F}$} & \multirow[t]{2}{*}{ Sig. } & \multirow[t]{2}{*}{$\mathrm{t}$} & \multirow[t]{2}{*}{ df } & \multirow{2}{*}{$\begin{array}{l}\text { Sig. } \\
\text { (2-tail } \\
\text { ed) }\end{array}$} & \multirow{2}{*}{$\begin{array}{c}\text { Mean } \\
\text { Difference }\end{array}$} & \multirow{2}{*}{$\begin{array}{l}\text { Std. Error } \\
\text { Difference }\end{array}$} & \multicolumn{2}{|c|}{$\begin{array}{l}\text { 99\% Confidence } \\
\text { Interval of the } \\
\text { Difference }\end{array}$} \\
\hline & & & & & & & & & Lower & Upper \\
\hline \multirow[b]{2}{*}{$\mathrm{X} 1$} & $\begin{array}{l}\text { Equal } \\
\text { variances } \\
\text { assumed }\end{array}$ & 8.244 & .028 & 3.062 & 6 & .022 & 1502.733 & 490.791 & -316.839 & 3322.306 \\
\hline & $\begin{array}{l}\text { Equal } \\
\text { variances } \\
\text { not } \\
\text { assumed }\end{array}$ & & & 2.304 & 2.110 & .141 & 1502.733 & 652.196 & $\begin{array}{c}-4432.71 \\
5\end{array}$ & 7438.182 \\
\hline \multirow[b]{2}{*}{$\mathrm{X} 2$} & $\begin{array}{l}\text { Equal } \\
\text { variances } \\
\text { assumed }\end{array}$ & .039 & .849 & 4.068 & 6 & .007 & 80718.133 & 19840.106 & $\begin{array}{c}7162.36 \\
8\end{array}$ & 154273.899 \\
\hline & $\begin{array}{l}\text { Equal } \\
\text { variances } \\
\text { not } \\
\text { assumed }\end{array}$ & & & 4.330 & 5.198 & .007 & 80718.133 & 18643.121 & $\begin{array}{c}6998.71 \\
7\end{array}$ & 154437.549 \\
\hline \multirow[b]{2}{*}{3} & $\begin{array}{l}\text { Equal } \\
\text { variances } \\
\text { assumed } \\
\end{array}$ & 4.569 & .076 & 1.205 & 6 & .274 & .206667 & .171544 & -.429321 & .842655 \\
\hline & $\begin{array}{l}\text { Equal } \\
\text { variances } \\
\text { not } \\
\text { assumed }\end{array}$ & & & 1.513 & 5.289 & .187 & .206667 & .136554 & -.328798 & .742131 \\
\hline
\end{tabular}

\section{Conclusion}

Based on the empirical analysis, it is concluded that both the amount (initially presented value) and the attitude of comment/ reaction, which are generated in advance before broadcasting, all positively influence the decision making to new TV content choice. People's heuristic judgment system seems to influence the consumption behavior of media content in a very 
short time. To sum up, the anchoring effect appears in TV content viewing consumption by communicating on online space and perceiving the degree of interest in a new TV content by the amount of comment. In a practical perspective, this study's finding has a meaningful suggestion that noise marketing in TV shows such as drama may do a harmful effect on the decision making to choose a new TV content.

On the other hand, TV series content is a kind of media content with the experience goods' characteristics. Having some break time (normally one week), connected next episodes will come to be chosen and watched again; audiences might switch their content choice to different TV contents after the experience of viewing the former episode. This pattern leads the investigator to have some extended research question, if the comment/reaction data value (initially presented value) created in advance before broadcasting positively influences on viewing behavior of the next coming episodes continuously until the end of whole episodes broadcasting. Or if a new, different theory can be discovered to affect strongly on the TV media content consuming behavior.

There is a perceived limitation to this study. While text mining, direct manual monitoring, and classification work (if the comment is positive or negative/ if the comment has nothing to do with the TV shows) were done for higher accuracy among the complex and ambiguous expressions in Korean. Because of this time-consuming editing process, the quantity of data from TV series' titles is limitedly less than data collected by crawling bot. For increasing the sample content data (the quantity of TV series titles), accurate and sensitive mining software programs are needed.

The integrated theoretical framework and empirical findings above provided by the present study should serve as a good start for future research. Extending the research dimension and condition, timeline perspective research (between before and live broadcasting service), platform comparison research (between the video service based platform like YouTube and terrestrial TV platform) can also be studied in the future. Using both automatically collected data and the experimental procedure method also can be a fruitful approach for future study.

\section{References}

[1] Tversky, A., \& Kahneman, D., “Judgment under uncertainty: Heuristics and biases,” Science, 185(4157), 1124-1131, 1974. Article (CrossRef Link).

[2] Kahneman, D., Wakker, P. P., \& Sarin, R., "Back to Bentham? Explorations of experienced utility,” The Quarterly Journal of Economics, 112(2), 375-406, 1997. Article (CrossRef Link).

[3] Tversky, A., \& Kahneman, D., "The Framing of Decisions and the Psychology of Choice," Covello V.T., Mumpower J.L., Stallen P.J.M., Uppuluri V.R.R. (eds) Environmental Impact Assessment, Technology Assessment, and Risk Analysis. NATO ASI Series (Series G: Ecological Sciences), vol 4. Springer, Berlin, Heidelberg, 1985. Article (CrossRef Link).

[4] Van Exel, N. J. A., Brouwer, W. B. F., van den Berg, B., \& Koopmanschap, M. A., "With a little help from an anchor: discussion and evidence of anchoring effects in contingent valuation,” The Journal of Socio-economics, 35(5), 836-853, 2006. Article (CrossRef Link).

[5] Holbrook, M. B., \& Hirschman, E. C., "The experiential aspects of consumption: Consumer fantasies, feelings, and fun,” Journal of Consumer Research, 9(2), 132-140, 1982.

Article (CrossRef Link).

[6] Guo, M., \& Chan-Olmsted, S. M., "Predictors of social television viewing: How perceived program, media, and audience characteristics affect social engagement with television programming,” Journal of Broadcasting \& Electronic Media, 59(2), 240-258, 2015. Article (CrossRef Link). 
[7] Chan-Olmsted, S. M., \& Park, J. S., "From on-air to online world: Examining the content and structures of broadcast TV stations' websites," Journalism \& Mass Communication Quarterly, 77(2), 321-339, 2000. Article (CrossRef Link).

[8] Nielsen, A. C., "What Americans do online: social media and games dominate activity," 2010.

[9] Smith, A., \& Boyles, J. L., “The rise of the “connected viewer.”,” Pew Research Center's Internet and American Life Project, 2012.

[10] Furnham, A., \& Boo, H. C., “A literature review of the anchoring effect,” The Journal of Socio-Economics, 40(1), 35-42, 2011. Article (CrossRef Link).

[11] Goldhaber, M. H., "The attention economy and the net,” First Monday, 2(4). 7 April, 1997. Article (CrossRef Link).

[12] Owen, B. M., Beebe, J., \& Manning, W., “TV Economics,” DC Heath, London, 1974.

[13] Webb, G.K., "The economics of cable television. Lexington,” MA: Lexington Books, 1983.

[14] Owen, B. M., \& Wildman, S. S., "Video economics,” La Editorial, UPR, 1992.

[15] Picard, R. G., "Historical trends and patterns in media economics," Handbook of Media Management and Economics, 23-36, 2006.

[16] Küng, L., "Does media management matter? Establishing the scope, rationale, and future research agenda for the discipline,” Journal of Media Business Studies, 4(1), 21-39, 2007. Article (CrossRef Link).

[17] Bucy, E. P., "Media credibility reconsidered: Synergy effects between on-air and online news,” Journalism \& Mass Communication Quarterly, 80(2), 247-264, 2003. Article (CrossRef Link).

[18] "How chatter matters in TV viewing," CTAM, May 4, 2012.

[19] Russell, C. A., Norman, A. T., \& Heckler, S. E., “The consumption of television programming: Development and validation of the connectedness scale," Journal of Consumer Research, 31(1), 150-161, 2004. Article (CrossRef Link).

[20] Gibs, J., \& Bruich, S., “Advertising effectiveness: Understanding the value of a social media impression,” New York, NY: The Nielsen Company, 2010

[21] Wang, J. C., \& Chang, C. H., "How online social ties and product-related risks influence purchase intentions: A Facebook experiment," Electronic Commerce Research and Applications, 12(5), 337-346, 2013. Article (CrossRef Link).

[22] McClellan, S., “The Hills' Is Alive: MTV Research Links Cross-Platform Marketing to Brand Affinity among Web Users,” AdWeek, 2008

[23] Shiloh, S., Salton, E., \& Sharabi, D., "Individual differences in rational and intuitive thinking styles as predictors of heuristic responses and framing effects,” Personality and Individual Differences, 32(3), 415-429, 2002. Article (CrossRef Link).

[24] Ariely, D., Loewenstein, G., \& Prelec, D., ““Coherent arbitrariness”: Stable demand curves without stable preferences,” The Quarterly Journal of Economics, 118(1), 73-106, 2003. Article (CrossRef Link).

[25] Mussweiler, T., Strack, F., \& Pfeiffer, T., “Overcoming the inevitable anchoring effect: Considering the opposite compensates for selective accessibility,” Personality and Social Psychology Bulletin, 26(9), 1142-1150, 2000. Article (CrossRef Link).

[26] Wansink, B., Kent, R. J., \& Hoch, S. J., “An anchoring and adjustment model of purchase quantity decisions,” Journal of Marketing Research, 35(1), 71-81, 1998. Article (CrossRef Link).

[27] Blankenship, K. L., Wegener, D. T., Petty, R. E., Detweiler-Bedell, B., \& Macy, C. L., "Elaboration and consequences of anchored estimates: An attitudinal perspective on numerical anchoring,” Journal of Experimental Social Psychology, 44(6), 1465-1476, 2008.

Article (CrossRef Link). 
[28] Wegener, D. T., Petty, R. E., Detweiler-Bedell, B. T., \& Jarvis, W. B. G., "Implications of attitude change theories for numerical anchoring: Anchor plausibility and the limits of anchor effectiveness,” Journal of Experimental Social Psychology, 37(1), 62-69, 2001. Article (CrossRef Link).

[29] Wegener, D. T., Petty, R. E., Blankenship, K. L., \& Detweiler-Bedell, B., "Elaboration and numerical anchoring: Implications of attitude theories for consumer judgment and decision making," Journal of Consumer Psychology, 20(1), 5-16, 2010. Article (CrossRef Link).

[30] Wilson, T. D., Houston, C. E., Etling, K. M., \& Brekke, N., "A new look at anchoring effects: basic anchoring and its antecedents," Journal of Experimental Psychology: General, 125(4), 387, 1996. Article (CrossRef Link).

[31] Epley, N., \& Gilovich, T., "When effortful thinking influences judgmental anchoring: differential effects of forewarning and incentives on self-generated and externally provided anchors," Journal of Behavioral Decision Making, 18(3), 199-212, 2005.

Article (CrossRef Link).

[32] Strack, F., \& Mussweiler, T., "Explaining the enigmatic anchoring effect: Mechanisms of selective accessibility," Journal of personality and social psychology, 73(3), 437, 1997. Article (CrossRef Link).

[33] Montpetit, M. J., Klym, N., \& Blain, E., "The future of mobile TV: When mobile TV meets the internet and social networking," Mobile TV: Customizing content and experience, pp. 305-326, 2010. Article (CrossRef Link).

[34] Pagani, M., \& Mirabello, A., "The influence of personal and social-interactive engagement in social TV web sites," International Journal of Electronic Commerce, 16(2), 41-68, 2011. Article (CrossRef Link).

[35] Ahn, J., Ma, K., Lee, O., \& Sura, S., "Do big data support TV viewing rate forecasting? A case study of a Korean TV drama," Information Systems Frontiers, 19(2), 411-420, 2017. Article (CrossRef Link).

[36] Van de Van, A. H., \& Ferry, D. L., "Measuring and assessing organization,” New York: Wiley Inter-science, 1980.

[37] Miles, J., "Tolerance and variance inflation factor," Encyclopedia of statistics in behavioral science, 2005. Article (CrossRef Link).

[38] O’brien, R. M., “A caution regarding rules of thumb for variance inflation factors,” Quality \& Quantity, 41(5), 673-690, 2007. Article (CrossRef Link). 


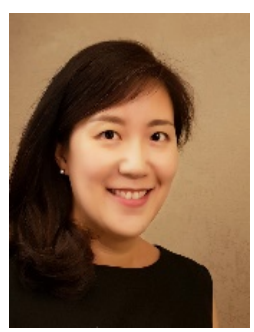

Alice Kyungran Ma is a doctoral student in Media \& Technology Management at Cologne University. She received the B.S. degree in Industrial Engineering at Korea University and her M.S. degree in Information Systems at Hanyang University. She has great interest in media consumers' behavior for video content media using user generated big data with behavioral economics perspective and consumer psychology.

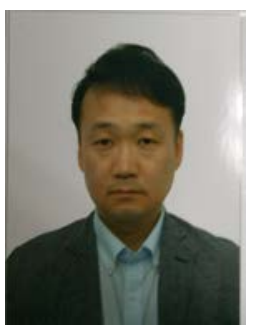

Jongchang Ahn is currently associate professor at the Department of Information Systems in Hanyang University. He received his B.S. degree in Economics at Korea University and his M.S. degree in Software Engineering from Sejong University. He received his Ph. D. in Information Systems from Hanyang University. He has great interest in Knowledge Management, Social Media \& Mass Media, and IT Users’ Behavior. 